\title{
Pengaruh PhytoRemediator Tanaman Kayu Apu (Pistia stratiotes) dan Kiambang (Salvinia molesta) pada Kualitas Air Graywater untuk Hidroponik Tanaman Selada (Lactuca sativa)
}

\author{
Oteng Haridjaja ${ }^{1}$, Wahyu Purwakusuma ${ }^{1}$, dan Ratih Safitri \\ ${ }^{1}$ Staf Departemen IImu Tanah dan Sumberdaya Lahan, Faperta-IPB, Jl Meranti, Kampus IPB \\ Darmaga, Bogor 16680 \\ ${ }^{2}$ Alumni Departemen Ilmu Tanah dan Sumberdaya Lahan, Faperta-IPB
}

\begin{abstract}
Graywater of domestic waste has a biodegradable organic matter characteristics which can be decreased by using waterwaste phytoremediator method. The objective of this research was to study the effect of Pistia Stratiotes and Salvinia Molesta on water quality for hydrophonic media of Lactuca Sativa production. Greenhouse experiments were conducted at Darmaga Research Station, Bogor. A complete factorial experimental design with three replications was used. The first factor was two waterwaste circulation remediator tank types (WWCRTT), and the second factor was a control, Pistia and Salvinia treatments. The results of these experiments showed that: the influence of plant has a significant difference to water COD at zero to one week after planting(WAP), and the influence of WWCRTT has also a significant difference to water COD at three WAP. The influence of WWCRTT has a significant difference to P-water content at zero, two, and three WAP. Plants, WWCRTT and their combinations have significant diference on NO3-water content at one WAP. The total of $P$ and NO3 water contents were not sufficient for plant growth, and the influence of flooding water and bad drainage can decrease plant yield.
\end{abstract}

Key words: graywater, hydrophonic, phytoremediator

\section{PENDAHULUAN}

Air merupakan kebutuhan dasar manusia dan sumberdaya yang perlu dijaga kelestariannya untuk kepentingan manusia dan lingkungan. Ketidakseimbangan antara ketersediaan air dan kebutuhan serta penggunaannya oleh manusia menyebabkan ketersediaan air merupakan satu masalah yang diperhitungkan, sehingga diperlukan perhatian dan penanganan yang serius. Selain faktor ketidakseimbangan, faktor pencemaran limbah juga merupakan hal yang perlu diperhatikan. Sering kali limbah dibuang begitu saja ke sungai atau dengan penanganan yang kurang memadai. Hal ini tentu akan berdampak negatif bagi masyarakat dan lingkungan. Salah satu agen utama pencemar lingkungan perairan adalah limbah domestik (limbah rumah tangga), dimana diperlukan pengolahan supaya limbah tersebut tidak langsung dibuang ke perairan melainkan dapat dimanfaatkan terlebih dahulu.

Limbah rumah tangga ini dibagi menjadi dua jenis yaitu blackwater dan greywater. Blackwater merupakan air limbah yang berasal dari kotoran manusia dan sisa hasil industri, sedangkan greywater yaitu air limbah yang berasal dari kamar mandi, dapur dan mesin cuci. Greywater lebih mudah didekomposisikan dan diolah serta mengandung sedikit bahan berbahaya dibandingkan blackwater, sehingga unsur yang terdapat dalam limbah tersebut dapat dimanfaatkan sebagai hara ataupun pupuk. Salah 
satu langkah yang dapat dilakukan yaitu dengan memanfaatkan tanaman air untuk menanggulangi jumlah pencemar dengan cara menyerap, mengumpulkan dan mendegradasi bahan-bahan pencemar tertentu yang terdapat dalam limbah tersebut atau yang kita kenal dengan phytoremediasi. Tanaman air yang digunakan adalah kayu apu (Pistia statiotes) dan kiambang (Salvinia molesta). Tanaman ini hidup dari menyerap udara dan unsur hara yang terkandung dalam air namun tanaman ini dinamakan floating plant karena akar tanaman tidak tertanam melainkan mengapung di air. Penelitian ini bertujuan untuk mengetahui karakteristik greywater terutama limbah kamar mandi, efektitivitas pengolahan limbah dengan tanaman air dan pengaruh hasil olahannya untuk tanaman selada yang ditanam secara hidroponik.

Pengolahan limbah dengan menggunakan tanaman air seperti kayu apu dan kiambang, diharapkan dapat mengurangi kadar zat-zat pencemar pada greywater dan hasil olahan tersebut dapat dimanfaatkan untuk budidaya tanaman selada hidroponik.

\section{BAHAN DAN METODE}

Penelitian ini terdiri dari dua tahap, yaitu penelitian pendahuluan dan penelitian utama. Penelitian dilakukan pada bulan Desember hingga Maret 2009 bertempat di rumah kaca Cikabayan, Laboratorium Fisika dan Konservasi Tanah dan Laboratorium Kimia dan Kesuburan Tanah Departemen IImu Tanah dan Sumberdaya Lahan, Fakultas Pertanian, Institut Pertanian Bogor.

Alat yang digunakan dalam penelitian ini adalah wadah penampung, wadah pengolahan, wadah hasil olahan limbah dan wadah (kontainer) media tanaman berukuran $75 \mathrm{~cm} \times 12 \mathrm{~cm} \times 10 \mathrm{~cm}$ serta alat untuk analisis laboratorium. Bahan-bahan yang digunakan adalah air limbah, tumbuhan air pistia dan salvinia, media tanam selada, benih tanaman selada dan bahan kimia untuk analisis laboratorium. Data hasil penggunaan air limbah disajikan pada Tabel 1.

Tabel 1. Data hasil penggunaan limbah

\begin{tabular}{clc}
\hline No. & \multicolumn{1}{c}{ Produk Limbah } & Banyaknya limbah/satu kali mandi \\
\hline 1 & Sabun (lifebouy) & $8.970 \mathrm{gram}$ \\
2 & Pasta Gigi (Pepsodent) & $15,875 \mathrm{ml}$ \\
3 & Shampoo (Sunsilk) & $5,460 \mathrm{ml}$ \\
\hline
\end{tabular}

Pembuatan air limbah yang menyerupai limbah asli

*Banyaknya penggunaan air limbah satu kali mandi per keluarga (4 orang)

Kerangka penelitian secara skematis disajikan pada Gambar 1.

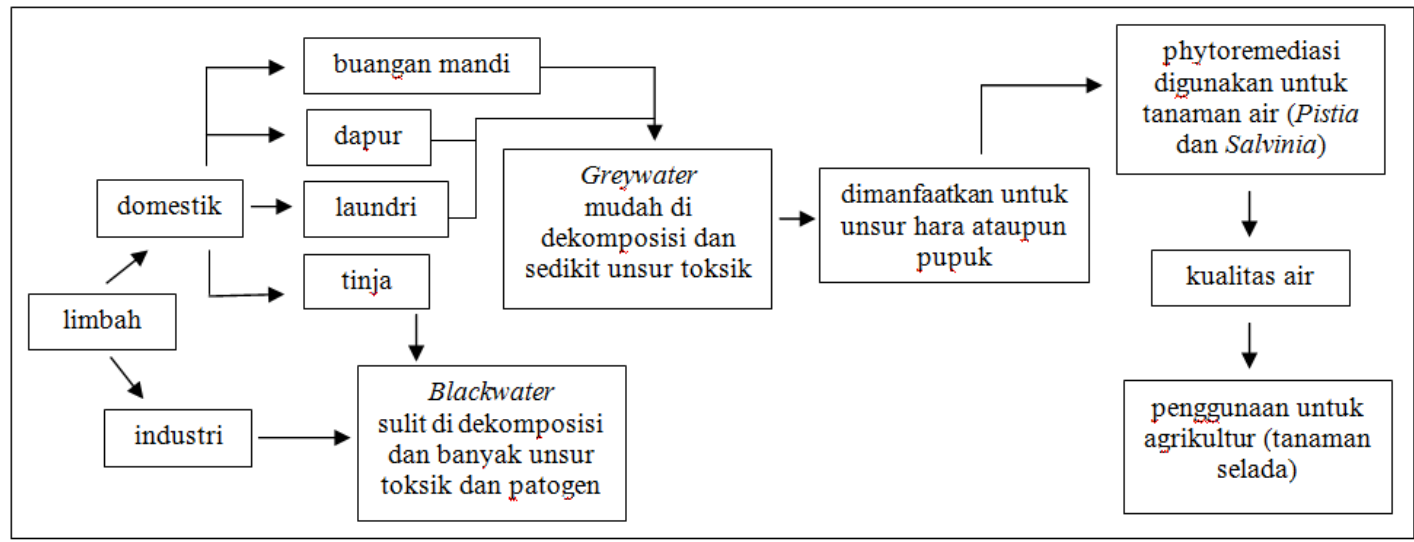

Gambar 1. Skema kerangka fikiran metode penelitian 
Penentuan biomassa diawali dengan menghitung waktu penggandaan (Doubling Time) dan Relative Growth Rate (RGR) (Gaudet in Mitchell, 1974).

$\mathrm{RGR}=\frac{\ln \mathrm{x}_{\mathrm{t}}-\ln \mathrm{x}_{0}}{\mathrm{t}} \mathrm{RGR}=\frac{\ln \mathrm{x}_{\mathrm{t}}-\ln \mathrm{x}_{\mathrm{0}}}{\mathrm{t}} \quad \mathrm{DT}=\frac{\ln 2}{\mathrm{RGR}} \mathrm{DT}=\frac{\ln 2}{\mathrm{RGR}}$

Ket: $\mathrm{X}_{0}=$ berat basah awal $(\mathrm{gr})$

$\mathrm{X}_{\mathrm{t}} \quad=$ berat basah akhir $(\mathrm{gr})$

$\mathrm{t} \quad=$ waktu

Benih selada disemaikan di dalam tray dengan media tanah dan pupuk kandang dengan perbandingan 1:1, hingga bibit tanaman berdaun 3-5 helai selanjutnya bibit dapat dipindahkan ke media tanam. Pada wadah penampung limbah diisi air limbah dan diisi ulang setiap dua kali sehari (menyerupai waktu mandi), percobaan ini dilakukan hingga pemanenan selada (4 MST).

Wadah pengolahan limbah menerapkan sistem bejana berhubungan dan gaya Archimedes. Pada bak pengolahan (treatment) ini terdapat tanaman air sebagai phytoremediator kemudian air hasil pengolahan limbah (effluent 1) mengalir secara gravitasi dari kontainer pertama hingga ke kontainer ke tiga secara sistem irigasi tetes (drip irrigation) kemudian dialirkan ke penampung hasil keluaran air (effluent 2).


Gambar 2. Skema alat dan denah penelitian; $P=$ pistia, $S=$ salvinia, $K=$ kontrol, $B 1=1$ bak remediasi dan $\mathrm{B} 2=3$ bak remediasi

Analisis dilakukan setiap minggu (0, 1, 2 dan 3 MST) terdiri dari COD, fosfor dan nitrat. Pengukuran karakter tanaman selada meliputi tinggi tanaman dan jumlah daun. Pada saat panen (4 MST) dilakukan pengukuran tinggi, jumlah daun, bobot total, bobot tajuk, bobot akar dan bobot kering tanaman selada, sedangkan untuk analisis jaringan tanaman terdiri dari fosfor dan nitrat.

Penelitian ini menggunakan Rancangan Acak Lengkap (RAL) Faktorial terdiri dari dua faktor yaitu bak remediasi (B1 dan B2) dan tumbuhan air (kontrol, pistia dan salvinia), dimana setiap perlakuan dilakukan pengulangan sebanyak tiga kali sehingga terdapat 18 satuan percobaan. Model rancangan statistik yang digunakan sebagai berikut:

$$
Y_{i j}=\mu+\alpha_{i}+\beta_{j}+\alpha_{i j} \beta_{j}+\varepsilon_{i j k}
$$

Ket : $\quad Y_{i j}=$ Respon pada perlakuan ke-i dan ke-j ulangan ke-k

$\mu=$ Rataan umum

$\alpha_{i}=$ Perlakuan taraf $\alpha$ ke- $\mathrm{i}$

$\beta_{\mathrm{j}}=$ Perlakuan taraf $\beta$ ke-j

$\alpha_{i} \beta_{j}=$ Interaksi perlakuan $\alpha$ ke-i dan $\beta$ ke-j

$\tau_{\mathrm{k}}=$ Rataan perlakuan ulangan ke-k

$\varepsilon_{\mathrm{ijk}}=$ Galat pada perlakuan $\mathrm{i}$ ulangan ke- $\mathrm{k}$ 


\section{HASIL PEMBAHASAN}

Pengamatan hari ke- 6 pada konsentrasi $25 \%$ keadaaan kayu apu mulai layu, ujung daun agak kering dan air keluarannya berwarna keruh, sedangkan pada konsentrasi $50 \%$ air hasil olahan berwarna lebih bening dibandingkan semua konsentrasi. Berdasarkan konsentrasi $75 \%$ tanaman mengalami pertumbuhan yang pesat tetapi akar tumbuhan pistia mengalami kerontokan dan hasil limbah berwarna keruh, sedangkan pada konsentrasi $100 \%$ semua daun pistia mati dan mengalami kerontokan dan pada air olahannya berwarna sangat keruh dan pekat.

Menurut Mursalin (2007) luas penutupan tanaman kayu apu yang digunakan untuk mengolah limbah kantin konsentrasi $75 \%$ yaitu sebesar $40 \%$ dari luas air limbah pada wadah. Luas penutupan ini digunakan untuk menghitung penyetaraan luas penutupan tanaman kiambang, sehingga didapatkan luas penutupannya sebesar $33 \%$. Pengamatan akhir luas penutupan kayu apu meningkat dari $40 \%$ menjadi $70-75 \%$, sedangkan pada kiambang luas penutupannya mening kat hingga $100 \%$.

\section{Kadar COD dalam Air}

Hasil penelitian menunjukkan kadar COD pada 0 dan 1 MST berbeda nyata $(\mathrm{P}<0,05)$ terhadap perlakuan bak remediasi, sedangkan perlakuan tanaman remediasi berbeda nyata terhadap kontrol pada 3 MST. Pada 2 MST tidak ada pengaruh yang nyata terhadap perlakuan bak remediasi maupun tanaman air (Tabel 1). Hal ini terjadi akibat penurunan COD diduga disebabkan oleh aktivitas dekomposisi bahan organik oleh mikroorganisme yang terdapat dalam air limbah.

Tabel 1. Rata-rata nilai COD (effluent1)

\begin{tabular}{|c|c|c|c|c|c|}
\hline \multicolumn{2}{|c|}{ Perlakuan } & $0 \mathrm{MST}$ & $1 \mathrm{MST}$ & $2 \mathrm{MST}$ & $3 \mathrm{MST}$ \\
\hline & & \multicolumn{4}{|c|}{ 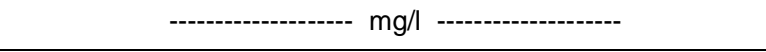 } \\
\hline \multirow{3}{*}{ Tanaman Air } & $P$ & $228,0 \quad b^{1)}$ & $147,4 \quad a$ & 196,5 & 55,1 \\
\hline & $S$ & $248,3 a b$ & $107,6 \quad b$ & 91,5 & 62,0 \\
\hline & K & $329,3 \quad a$ & $143,4 a b$ & 102,9 & 89,6 \\
\hline \multirow{2}{*}{ Bak Remediasi } & $\mathrm{B} 1$ & $278,7^{2)}$ & 134,6 & 144,7 & $92,3 \mathrm{a}$ \\
\hline & B2 & 258,4 & 131,0 & 116,0 & $45,5 \mathrm{~b}$ \\
\hline \multirow{6}{*}{$\begin{array}{c}\text { Kombinasi } \\
\text { Tanaman air dan } \\
\text { Bak remediasi }\end{array}$} & PB1 & 238,1 & 143,4 & 231,1 & 81,3 \\
\hline & PB2 & 217,9 & 151,4 & 162,0 & 28,9 \\
\hline & SB1 & 248,3 & 95,6 & 134,1 & 100,5 \\
\hline & SB2 & 248,3 & 79,7 & 71,7 & 23,4 \\
\hline & KB1 & 349,6 & 164,7 & 68,9 & 95,0 \\
\hline & KB2 & 309,1 & 122,2 & 114,2 & 84,1 \\
\hline
\end{tabular}

1) 2) Angka yang diikuti oleh huruf yang sama tidak menunjukan perbedaan yang nyata menurut uji tukey $5 \%$; $\mathrm{P}=$ Pistia, $\mathrm{S}=$ Salvinia, $\mathrm{K}=$ Kontrol, 1 = 1 Bak remediasi, 2 = 3 Bak remediasi 


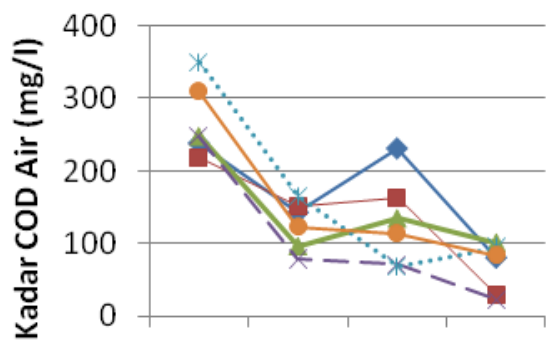

(a) $0 \stackrel{1}{1}{ }^{2}$ Mingu Setelah Tanam

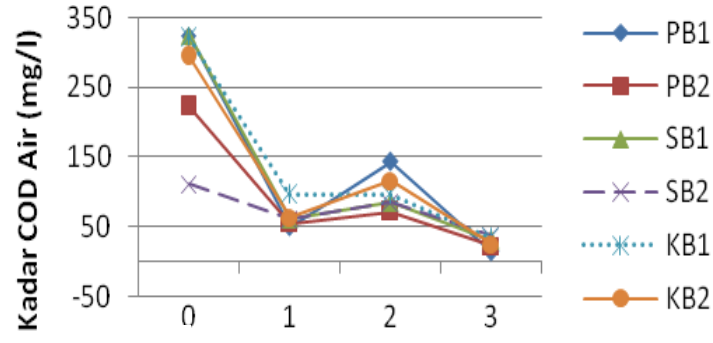

(b) Minggu Setelah Tanam

Gambar 3 Kadar COD air ( $\mathrm{mg} / \mathrm{l})$ pada kombinasi tanaman air dan bak remediasi; (a) Effluent 1, (b) Effluent 2, $\mathrm{P}=$ pistia, $\mathrm{S}=$ salvinia, $\mathrm{K}=$ kontrol, $\mathrm{B} 1=1$ bak remediasi, $\mathrm{B} 2$ = 3 bak remediasi.

Gambar 3 menunjukkan grafik COD pada effluent 1 dan effluent 2 tidak berbeda, nilai kadar COD menurun pada waktu 1 MST kemudian naik kembali pada 2 MST dan menurun kembali pada 3 MST. Penurunan COD disebabkan oleh proses penguraian atau perubahan bentuk senyawa yang kurang stabil karena pengaruh radiasi sinar ultraviolet, oksidasi dan reduksi (Stowellet et al., 1980 dalam Khiatuddin, 2003).

\section{Kadar Fosfor dalam Air dan Tanaman}

Nilai rata-rata fosfor dalam air berdasarkan uji pada Tabel 2, perlakuan tanaman air tidak berpengaruh nyata $(P>0,05)$ pada semua waktu MST, tetapi pada perlakuan bak remediasi berpengaruh nyata. Secara umum kadar $\mathrm{P}$ hasil olahan tanaman air lebih rendah dibandingkan kontrol.

Tabel 2 Rata-rata nilai fosfor (Effluent 1)

\begin{tabular}{|c|c|c|c|c|c|}
\hline \multicolumn{2}{|l|}{ Perlakuan } & $0 \mathrm{MST}$ & $1 \mathrm{MST}$ & $2 \mathrm{MST}$ & $3 \mathrm{MST}$ \\
\hline & & \multicolumn{4}{|c|}{-------------------- ppm --------------------- } \\
\hline \multirow{3}{*}{ Tanaman Air } & $P$ & $0,55^{1)}$ & 1,27 & 2,17 & 1,66 \\
\hline & S & 0,68 & 1,35 & 2,79 & 1,43 \\
\hline & $\mathrm{K}$ & 0,55 & 1,69 & 2,57 & 1,27 \\
\hline \multirow{2}{*}{ Bak Remediasi } & B1 & $0,75 \mathrm{a}^{2)}$ & 1,34 & $2,95 \mathrm{a}$ & $1,68 \mathrm{a}$ \\
\hline & B2 & $0,43 \quad b$ & 1,53 & $2,06 \mathrm{~b}$ & $1,22 b$ \\
\hline \multirow{6}{*}{$\begin{array}{c}\text { Kombinasi Tanaman air dan } \\
\text { Bak remediasi }\end{array}$} & PB1 & $0 ., 75$ & 1,15 & 2,77 & 1,87 \\
\hline & PB2 & 0,35 & 1,38 & 1,56 & 1,44 \\
\hline & SB1 & 0,88 & 1,46 & 3,32 & 1,85 \\
\hline & SB2 & 0,47 & 1,24 & 2,25 & 1,00 \\
\hline & KB1 & 0,62 & 1,41 & 2,76 & 1,31 \\
\hline & KB2 & 0,47 & 1,96 & 2,38 & 1,23 \\
\hline
\end{tabular}

; $\mathrm{P}=$ Pistia, $\mathrm{S}=$ Salvinia, $\mathrm{K}=$ Kontrol, 1 = 1 Bak remediasi, $2=3$ Bak remediasi 


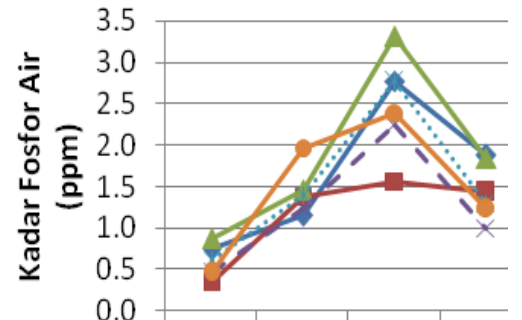

(a) $\stackrel{0}{0} \stackrel{2}{2} \stackrel{3}{\text { Minggu Setelah Tanam }}$

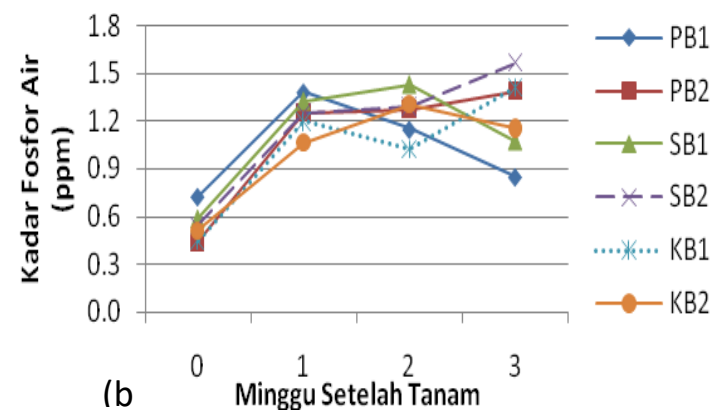

Gambar 4 Kadar fosfor air (mg/l) pada kombinasi tanaman air dan bak remediasi; (a) Effluent 1, (b) Effluent 2, $\mathrm{P}=$ pistia, $\mathrm{S}=$ salvinia, $\mathrm{K}=$ kontrol, $\mathrm{B} 1=1$ bak remediasi, $\mathrm{B} 2 \mathrm{=} 3$ bak remediasi.

Kadar terendah effluent 1 yaitu pada perlakuan PB2 dan SB2 dimana pengolahan air dilakukan oleh tanaman air dan limbah melewati 2 bak remediasi (Gambar 4). Menurut Morgan (1999) kadar nutrisi hidroponik untuk tanaman selada sebesar 15-90 mg/l, sehingga kadar ini tergolong masih kurang untuk pertumbuhan tanaman selada secara hidroponik.

Kadar P dalam jaringan tanaman selada pada perlakuan PB1, PB2, SB1, SB2, KB1, dan KB2 yaitu sekitar 0,04-0,068, 0,048-0,101, 0,07-0,79, 0,064-0,103, 0,69-0,99, $0,62-0,93 \%$. Nilai ini dikatakan rendah dan belum memenuhi konsentrasi nutrisi $P$ dalam jaringan tanaman selada sehat yaitu 0,5-0,9 \% (Gerber, 1985 dalam Napitupulu, 2003). Kadar fosfor ramuan pupuk tanaman selada untuk hidroponik sekitar 45 ppm, sehingga kurangnya unsur hara pada air effluent 1 menyebabkan terjadinya kahat $P$ pada tanaman selada.

\section{Kadar Nitrat dalam Air dan Tanaman}

Tabel 3 menunjukkan adanya perbedaan yang nyata $(P<0,05)$ antara perlakuan tanaman air dengan bak remediasi dan kombinasinya pada $1 \mathrm{MST}$, tetapi pada 2 MST kadar nitrat berbeda nyata hanya pada perlakuan bak remediasi, sedangkan pada 0 MST dan 3 MST kadar nitrat tidak berbeda nyata terhadap kontrol. Kadar nitrat pada perlakuan $\mathrm{P}, \mathrm{S}$ dan $\mathrm{K}$ secara berurutan yaitu sekitar $0,10-0,59,0,02-0,48$ dan 0,04-0,37 ppm.

Tabel 3 Rata-rata nilai nitrat (Effluent 1)

\begin{tabular}{|c|c|c|c|c|c|c|}
\hline \multirow{2}{*}{ Perlakuan } & & \multicolumn{2}{|l|}{0 MST } & $1 \mathrm{MST}$ & 2 MST & \multirow[t]{2}{*}{$3 \mathrm{MST}$} \\
\hline & & & & ---------. & --------- & \\
\hline \multirow{3}{*}{ Tanaman Air } & $P$ & 0,13 & 1) & $0,11 \mathrm{~b}$ & 0,28 & 0,12 \\
\hline & $S$ & 0,15 & & $0,44 a$ & 0,14 & 0,20 \\
\hline & $\mathrm{K}$ & 0,14 & & $0,04 \mathrm{~b}$ & 0,18 & 0,15 \\
\hline \multirow{2}{*}{ Bak Remediasi } & $\mathrm{B} 1$ & 0,19 & 2) & $0,32 \mathrm{a}$ & 0,29 a & 0,17 \\
\hline & $\mathrm{B} 2$ & 0,09 & & $0,06 \mathrm{~b}$ & $0,11 b$ & 0,13 \\
\hline \multirow{6}{*}{$\begin{array}{c}\text { Kombinasi Tanaman air dan } \\
\text { Bak remediasi }\end{array}$} & PB1 & 0,59 & 3) & $0,10 a$ & 0,41 a & 0,37 \\
\hline & PB2 & 0,33 & & $0,05 \mathrm{~b}$ & $0,17 \mathrm{~b}$ & 0,18 \\
\hline & SB1 & 0,40 & & 0,02 a & 0,48 a & 0,19 \\
\hline & SB2 & 0,18 & & $0,08 \mathrm{~b}$ & $0,23 \mathrm{~b}$ & 0,16 \\
\hline & KB1 & 0,20 & & 0,04 a & 0,19 a & 0,15 \\
\hline & KB2 & 0,37 & & $0,27 \mathrm{~b}$ & $0,37 \mathrm{~b}$ & 0,14 \\
\hline
\end{tabular}


Pada awal masa tanam 0 MST dan 1 MST kadar nitrat menurun drastis kemudian meningkat kembali pada 2 MST dan menurun kembali pada akhir percobaan (Gambar 5). Penghilangan nitrogen dalam air buangan dilakukan dengan memanfaatkan kemampuan nitrat sebagai penerima elektron dengan cara membiarkan ion nitrat mengoksidasi metanol melalui bakteri di bawah keadaan kekurangan oksigen. Reaksi $\mathrm{N}$ dalam air akan terjadi seperti berikut ini (Lewis,1986):

$5 \mathrm{CH}_{3} \mathrm{OH}+6 \mathrm{NO}_{3}{ }^{-}+6 \mathrm{H}^{+} \rightarrow 5 \mathrm{CO}_{2}+3 \mathrm{~N}_{2} \uparrow+12 \mathrm{H}_{2} \mathrm{O}$
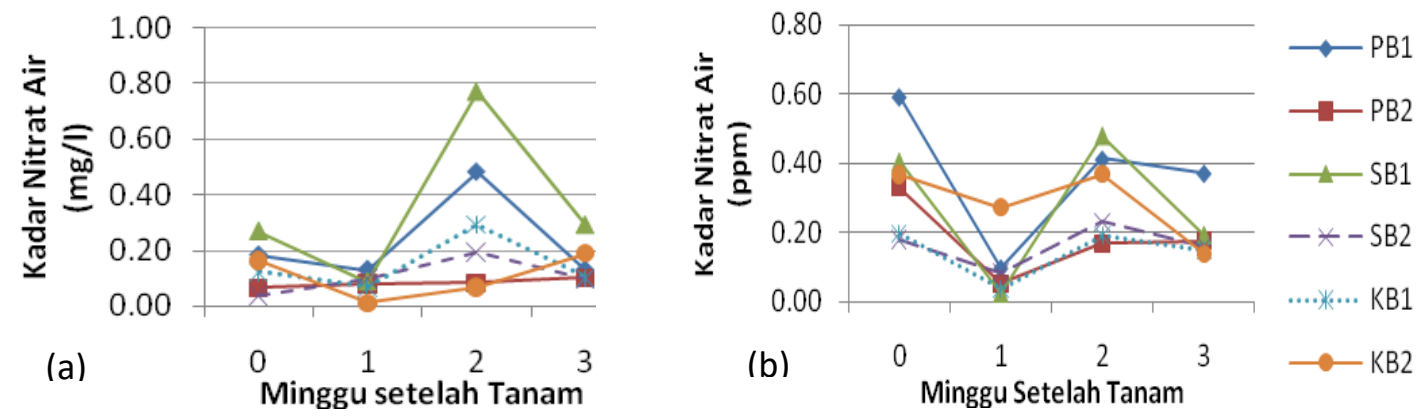

Gambar 5 Kadar nitrat air (mg/l) pada kombinasi tanaman air dan bak remediasi; keterangan sama seperti Gambar 4.

\section{Pertumbuhan Tanaman Selada}

\section{Tinggi Tanaman Selada}

Nilai rata-rata tinggi tanaman selada pada S1T1, K1T1, dan P2T2 hingga akhir pengamatan berturut-turut adalah 7,08, 13,09 dan 18,20 cm (Gambar 6a), sedangkan jumlah daun selada pada perlakuan P1T1, P1T2, P1T3, P2T1, P2T2, P2T3, S1T1, S1T2, S1T3, S2T1, S2T2, S2T3, K1T1, K1T2, K1T3, K2T1, K2T2 dan K2T3 hingga akhir pengamatan yaitu $4,3,5,1 ; 5,7 ; 5,1 ; 5,6 ; 5,4 ; 4 ; 5,2 ; 5,4 ; 5,1 ; 6,1 ; 6 ; 5,3 ; 5 ; 6,3 ; 5,3 ; 6,3$ dan 6,3 helai (Gambar $6 b$ ). Keadaan ini terjadi akibat adanya genangan air pada media pasir yang mengakibatkan kondisi anaerob di sekitar perakaran tanaman selada, sehingga akar mengalami kekurangan oksigen yang cukup berat. Menurut Kawase (1981) tanaman yang kekurangan oksigen akan mengalami klorosis pada daun, penurunan pertumbuhan akar dan batang, kematian akar, peningkatan serangan hama dan penyakit, kehilangan hasil dan akhirnya tanaman akan mati.

Selain kondisi tersebut temperatur yang tinggi pada suhu rumah kaca $\left(26-35^{\circ} \mathrm{C}\right)$ dapat menyebabkan tanaman selada mengalami stress dan kelayuan sementara. Temperatur yang tinggi dapat menyebabkan kerusakan yang berat pada daun-daun tanaman dan kerusakan jaringan tanaman akibat gangguan metabolisme sel (Fitter, 1991). Menurut Morgan (1999) saat temperatur tinggi jumlah oksigen yang terkandung dalam larutan hara akan menurun cepat dan meningkatkan laju transpirasi dari sistem akar.

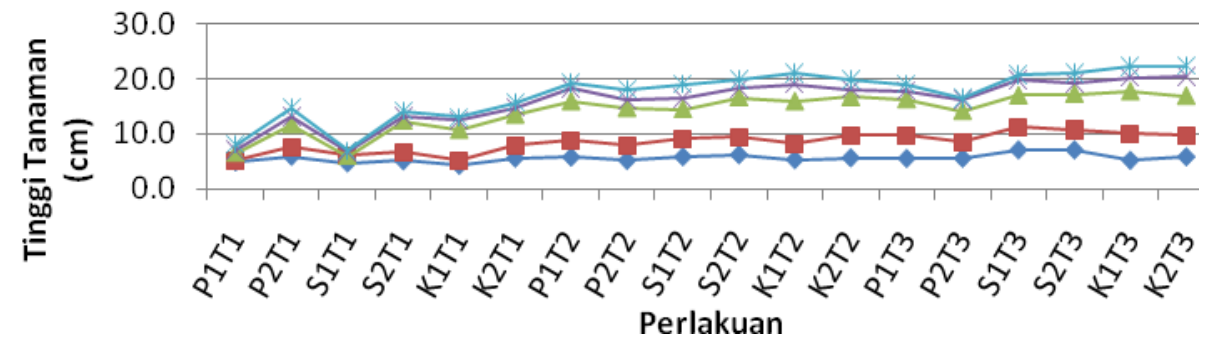




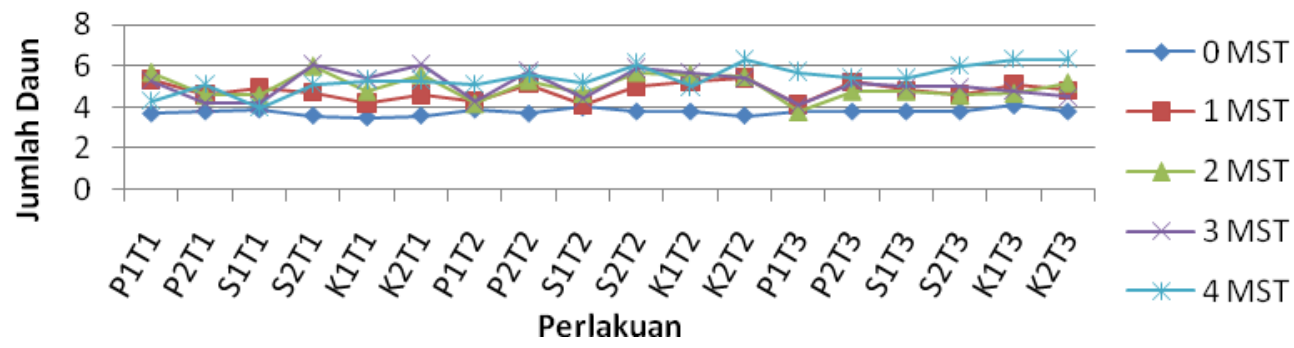

Gambar 6 Grafik rata-rata (a) tinggi tanaman dan (b) jumlah daun tanaman selada pada kombinasi penggunaan tanaman air dan kontainer tanaman selada; $\mathrm{P} 1=$ pistia (bak 1), P2 = pistia (bak 3), S1 = salvinia (bak 1), S2 = salvinia (bak 3), $\mathrm{K} 1=\operatorname{kontrol}($ bak 1$), \mathrm{K} 2=$ kontrol $($ bak 3$), \mathrm{T} 1=$ talang $($ kontainer 1$), \mathrm{T} 2=$ talang 2 (kontainer 2).

\section{Hasil Panen}

Hasil panen tanaman selada pada setiap perlakuan tidak berbeda nyata $(P>0,05)$. Tanaman selada sudah layak dikonsumsi namun belum layak untuk dipasarkan karena belum mencapai bobot yang ideal untuk panen selada. Menurut Rubatzky dan Yamaguchi (1998) bobot ideal tanaman selada yang cocok untuk dipasarkan berkisar antara 100-400 g. Bobot basah (utuh) rata-rata tanaman selada perlakuan PB1, PB2, SB1, SB2, KB1 dan KB2 yang dipanen pada 4 MST berturut-turut adalah 3,22; 4,94; 3,$38 ; 4,71 ; 3,72$ dan 4,15 gram (Gambar 7). Pertumbuhan tanaman selada pada percoban memiliki ukuran tinggi, batang dan daun serta akar yang kecil (Gambar 8).

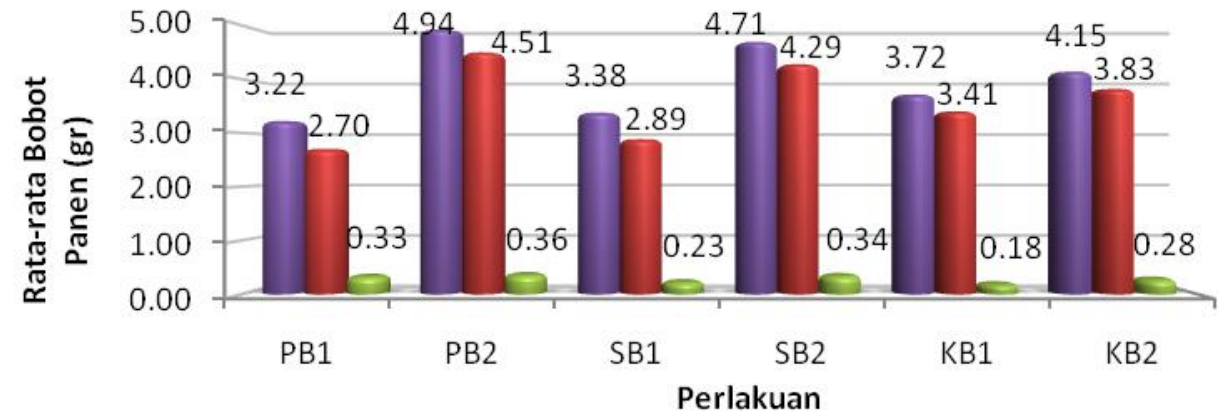

Bobot Basah Bobot Tajuk $\square$ Bobot Akar

Gambar 7 Rata-rata bobot panen selada pada kombinasi tanaman air dan bak remediasi; keterangan sama seperti Gambar 4.

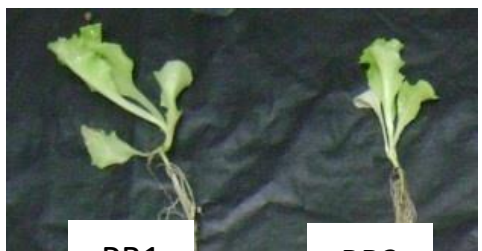

PB1

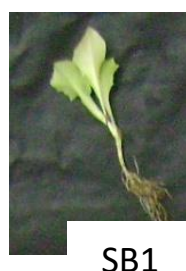

SB1



SB2

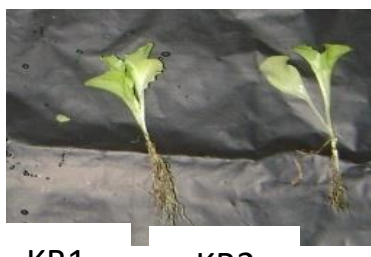

KB2

Gambar 8 Hasil panen tanaman selada pada percobaan umur 4 MST (Kontainer 1)

Kurang optimalnya pertumbuhan tanaman selada pada percobaan ini disebabkan oleh terganggunya sistem drainase akibat banyaknya pasir yang ikut terbawa sehingga menyumbat lubang pengeluaran talang dan menimbulkan genangan pada 
talang media tanam. Tingkat kematian tanaman selada yang ditanam pada percobaan sangat besar $( \pm 32 \%)$ yaitu pada perlakuan kontrol tanaman yang mati sebanyak $\pm 21 \%$ dan pada perlakuan pistia sekitar $\pm 10 \%$.

\section{SIMPULAN DAN SARAN}

Karakteristik fisik greywater yaitu zat padat terlarut dan tersuspensi memiliki nilai yang tidak melebihi kadar baku mutu air limbah, sedangkan karakteristik kimia greywater seperti Biochemical Oxygen Demand (BOD) dan Chemical Oxygen Demand (COD) memiliki nilai yang tinggi dan melebihi kadar baku mutu air limbah.

Tanaman kayu apu (Pistia stratiotes) paling efektif dalam memperbaiki kualitas air limbah kamar mandi buatan dibandingkan kiambang (Salvinia molesta). Namun secara umum penggunaan kedua tanaman tersebut dapat memperbaiki kualitas air limbah hingga memenuhi kadar baku mutu air limbah.

Kadar nitrat dan fosfor pada effluent 1 terbilang rendah sehingga belum mencukupi kebutuhan tanaman selada. Hal ini menyebabkan terjadinya kahat hara nitrat maupun fosfor, sehingga bobot panen tanaman selada kurang optimal dan tingkat kematian selada pada pecobaan sangat besar $( \pm 32 \%)$.

Perlu adanya penelitian lebih lanjut dengan penambahan unsur hara untuk tanaman selada dan penggunaan media tanam dan metode hidroponik yang berbeda sehingga dapat mengurangi penggenangan air maupun drainase yang buruk.

\section{DAFTAR PUSTAKA}

Fitter, A. H dan R. K. M. Hay. 1991. Fisiologi lingkungan tanaman. Gajah Mada University Press. Yogyakarta.

Kawase, M. 1981. Anatomical and morphological adaptation of plant to water logging. Hortscience. 16 (1) : 30-33.

Lewis, O. A. M. 1986. Plants and nitrogen. Southampon. The Camelot Press, Ltd.

Morgan, L. 1999. Hydroponics lettuce production. Casper Publ, Ltd. Narrabean. Australia. $102 \mathrm{p}$.

Mursalin. 2007. Pemanfaatan kayu apu (Pistia stratiotes), kiambang (Salvinia molesta) dan gulma itik (Lemna perpusilla) dalam memperbaiki kondisi air limbah kantin. Departemen Menejemen Sumberdaya Perairan. Fakultas Perikanan dan Kelautan. Institut Pertanian Bogor. Bogor.

Napitupulu, L. 2003. Pengaruh aplikasi pupuk daun dalam sumber nutrisi berbeda pada teknologi hidroponik sistem terapung tanaman selada (Lactuca sativa L. Var Grand Raphids). Skripsi. Departemen Budidaya Pertanian, Fakultas Pertanian. Institut Pertanian Bogor. Bogor.

Rubatzky, E. dan M. Yamaguchi. 1998. Sayuran dunia: prinsip, produksi, dan gizi, jilid 2. Penerbit ITB. Bandung. 